\title{
G-proteins coupled to phosphoinositide hydrolysis in the cochlear and vestibular sensory epithelia of the rat are insensitive to cholera and pertussis toxins
}

\author{
Kaoru Ogawa, Jochen Schacht * \\ Kresge Hearing Research Institute, University of Michigan, 1301 East Ann Street, Ann Arbor, MI 48109-0506, USA
}

(Received 2 August 1993; Revision received 16 November 1993; Accepted 22 November 1993)

\begin{abstract}
In the cochlear (CSE) and vestibular sensory epithelia (VSE), phosphoinositides are hydrolyzed in response to stimulation of phospholipase $C$ (PLC) by cholinergic muscarinic and purinergic $P_{2 y}$ agonists. Such receptor-mediated activation of PLC is expected to be coupled through guanine nucleotide-binding proteins (G-proteins). Although several classes of G-proteins have been identified in the inner ear, nothing is known about the type of G-proteins associated with the phosphoinositide second messenger system in CSE and VSE. Phosphoinositide hydrolysis was determined by the release of radiolabeled inositol phosphates (InsPs). Ten $\mathrm{mM} \mathrm{NaF}$ plus $10 \mu \mathrm{M} \mathrm{AlCl}_{3}$ increased basal InsPs accumulation 2-fold in both CSE and VSE of the rat. Release of InsPs was also enhanced by guanosine $5^{\prime}-\mathrm{O}$-(3-thiotriphosphate) (GTP- $\gamma$-S) in saponin-permeabilized tissues. Furthermore, release of InsPs stimulated by both carbamylcholine (CCh) and adenosine 5 -O-[3-thiotriphosphate] (ATP- $y$-S) was significantly inhibited by $100 \mu \mathrm{M}$ guanosine 5'-O-[2-thiodiphosphate] (GDP- $\beta$-S). These results strongly suggest the involvement of G-proteins in the receptor-PLC coupling in CSE and VSE. ADP-ribosylation in membrane fractions of CSE and VSE in the presence of cholera toxin (CTX) or pertussis toxin (PTX) indicated the existence of $\mathrm{G}_{\mathrm{s}}$ - and $\mathrm{G}_{\mathrm{i}}$-type G-proteins. However, neither CTX nor PTX affected basal or agonist-stimulated release of InsPs. These observations suggest that muscarinic and $P_{2 y}$ purinergic receptors are coupled to PLC via CTX- and PTX-insensitive G-proteins in CSE and VSE.
\end{abstract}

Key words: G-protein; Inositol phosphate; ADP-ribosylation; Cholera toxin; Pertussis toxin; Cochlea; Vestibule; Rat

\section{Introduction}

Guanine nucleotide-hinding proteins (G-proteins) couple plasma membrane receptors to their effector enzymes in several signal transduction systems. Most notably, specific members of this protein 'superfamily' mediate the hormonal stimulation of adenylate cyclase $\left(G_{s}\right)$, phospholipase $C\left(G_{p}\right.$; also designated $\left.G_{q}\right)$, and cyclic GMP-dependent phosphodiesterase $\left(G_{t}\right)$; the inhibition of adenylate cyclase $\left(G_{i}\right)$; or are implicated in the regulation of ion channels $\left(G_{i}, G_{o}\right)$. G-proteins are heterotrimers consisting of $\alpha, \beta$ and $\gamma$ subunits; $\alpha$ subunits have specific structural elements and distinguish different G-proteins, while the amino acid sequences of $\beta$ and $\gamma$ subunits are more conserved. G-proteins are activated by the receptor-catalyzed ex-

* Corresponding author. Fax: (313) 764-0014. change of guanosine diphosphate (GDP) for guanosinc triphosphate (GTP) on the $\alpha$ subunit, and inactivated by the subsequent hydrolysis of GTP to GDP. While the $\alpha$ subunit has long been recognized as an allosteric effector of its target enzymes, recent evidence indicates that $\beta$ and $\gamma$ subunits also affect enzyme activity (for reviews see Sternweis and Smrcka, 1992; Hepler and Gilman, 1992).

G-proteins can be classified by their differential sensitivity to cholera (CTX) and pertussis (PTX) toxins. These toxins catalyze the ADP-ribosylation of specific $\alpha$-subunits leading to activation of $G_{\mathrm{s}}$ by CTX or to inactivation of $G_{i}, G_{o}$ and $G_{t}$ by PTX (Gill and Meren, 1978; Cassel and Pfeuffer, 1978; Katada and Ui, 1982; see also Gilmann, 1987, for review). In contrast, G-proteins which couple muscarinic receptors to the phosphoinositide second messenger system $\left(\mathrm{G}_{\mathrm{p}}\right)$ are mostly insensitive to CTX or PTX action (Masters et al., 1985; Dunlop and Larkins, 1986; Helper and Harden, 1986; Sasaguri et al., 1986; Schnefel et al., 1988; Fleming et 
al., 1989). Only in a few cell types has the agoniststimulated accumulation of inositol trisphosphate (Ins $\mathrm{P}_{3}$ ) been suggested to be blocked by PTX, implying the involvement of $G_{i}$ or $G_{n}$-like proteins.

In the cochlear (CSE) and vestibular sensory epithelia (VSE) of the guinea pig and the rat, the release of InsPs is stimulated by cholinergic muscarinic and purinergic $\mathrm{P}_{2 \mathrm{y}}$ receptors (Guiramand et al., 1990; Niedzielski and Schacht, 1991, 1992; Niedzielski et al., 1992; Ogawa and Schacht, 1993). Several types of G-proteins have also been described in the organ of Corti of the guinea pig, namely $\alpha$-subunits of $\mathrm{G}_{\mathrm{i}}\left(\mathrm{G}_{\mathrm{i} 1}, \mathrm{G}_{\mathrm{i} 2}\right.$ and $\left.\mathrm{G}_{\mathrm{i} 3}\right)$, $G_{o}$ (Canlon et al., 1991) and of $G_{s}$ (Tachibana et al., 1992). However, $G_{p}$ which is most likely associated with the phosphoinositide second messenger system has not yet been demonstrated in the inner ear. In this study, therefore, we investigated the presence of $G_{p}$ in the CSE and VSE and classified G-proteins using CTX and PTX.

\section{Materials and methods}

\section{Materials}

Fischer-344 rats ( 3 month-old, male; from Charles River Inc., Kingston, NY) were used in this study. The care and use of animals was reviewed under grant DC-00078 and supervised by the University of Michigan Unit on Laboratory Animal Medicine.

myo- $\left[{ }^{3} \mathrm{H}\right]$ inositol (specific activity $82 \mathrm{Ci} / \mathrm{mmol}$ ) and $\left.{ }^{32} \mathrm{P}\right]$ nicotinamide adenine dinucleotide (NAD; specific activity $\sim 1000 \mathrm{Ci} / \mathrm{mmol}$ ) were obtained from Amersham Co. (Arlington Heights, IL); Hanks' balanced salt solution (HBSS) from Gibco BRL Life Technologies Inc. (Gaithersburg, MD). Other reagents were purchased from Sigma Chemical Co. (St. Louis, MO).

\section{Tissue preparation}

The otic capsules were quickly removed from the temporal bones and placed in incubation buffer at room temperature. The incubation buffer was HBSS with $5 \mathrm{mM}$ sodium $N$-2-hydroxyethylpiperazine- $N$ '-2ethanesulfonic acid (HEPES) gassed with $95 \% \mathrm{O}_{2} / 5 \%$ $\mathrm{CO}_{2}$ for $30 \mathrm{~min}$; its final $\mathrm{pH}$ was adjusted to 7.4 with $\mathrm{NaOH}$ and osmolality to $300 \pm 2$ mOsm with $\mathrm{NaCl}$. The CSE consisting of inner and outer hair cells, supporting cells, basilar membrane and lateral part of the spiral limbus, and VSE consisting of macula utriculi, macula sacculi and cristae ampullares of semicircular canals, were isolated by microdissection, transferred into the incubation buffer and kept at room temperature.

\section{Assay of inositol phosphate release}

Details of the incubation procedure were as previously reported (Ogawa and Schacht, 1993). The CSE and VSE were pre-incubated in the absence or presence of CTX or PTX for $2 \mathrm{~h}$ at $37^{\circ} \mathrm{C}$ in $50 \mu \mathrm{l}$ of incubation buffer and incubated for another $2 \mathrm{~h}$ with 1 $\mathrm{mM}$ cytidine and $16 \mu \mathrm{Ci} m y o-\left[{ }^{3} \mathrm{H}\right]$ inositol to label phosphoinositide lipids. After removing the myo- $\left[{ }^{3} \mathrm{H}\right]$ inositol-containing medium, tissues were washed twice with $0.5 \mathrm{ml}$ of non-radioactive buffer. In experiments using permeabilized cells, tissues were treated for 5 min with $50 \mu \mathrm{l}$ of $50 \mu \mathrm{g} / \mathrm{ml}$ saponin. Tissues were then incubated in $90 \mu \mathrm{l}$ of buffer with $10 \mathrm{mM} \mathrm{LiCl}$ for 10 min, after which $10 \mu \mathrm{l}$ of buffer with agonists or antagonists were added. Following $30 \mathrm{~min}$ of incubation at $37^{\circ} \mathrm{C}$, hydrolysis of phosphoinositides was terminated by the addition of $300 \mu \mathrm{l}$ of chloroform/ methanol $(1: 2$, by vol). Prior to separation of the aqueous and chloroform phases, $100 \mu \mathrm{l}$ of a phytic acid hydrolysate (prepared by heating $4 \mathrm{mg}$ phytic acid in 1 $\mathrm{ml}$ of $30 \mathrm{mM}$ acetic acid/ $65 \mathrm{mM}$ sodium acetate for 48 $h$ at $95^{\circ} \mathrm{C}$, quenching with $20 \mu \mathrm{l}$ of $1 \mathrm{~N} \mathrm{NaOH}$ and diluting 1:100 with $\mathrm{H}_{2} \mathrm{O}$ ) and $200 \mu \mathrm{l}$ of chloroform with bovine brain extract $(0.2 \mathrm{mg}$ of Sigma type IV/ml) were added as carriers to minimize loss of radiolabeled inositol phosphates and lipids during the isolation procedures.

InsPs in the aqueous phase were separated from myo-inositol on a Dowex-1 formate column as described previously (Berridge et al., 1983; Dean and Beaven, 1989) with minor modifications (Niedzielski et al., 1992; Ogawa and Schacht, 1993). Protein content of each sample was measured by Bradford's method (Bradford, 1976).

\section{$\left.{ }^{32} P\right] A D P$-ribosylation}

The CSE and VSE were incubated for $4 \mathrm{~h}$ at $37^{\circ} \mathrm{C}$ in $50 \mu \mathrm{l}$ of buffer with or without $1 \mu \mathrm{g} / \mathrm{ml} \mathrm{CTX}$ or PTX. Judging from the reproducibility of several ribosylation experiments, this preincubation did not adversely affect the tissues at least not for the purposes of these experiments. Then, tissues were washed twice and homogenized with a microhomogenizer in $10 \mathrm{mM}$ sodium HEPES containing $10 \mathrm{mM} \mathrm{MgCl}_{2}, 0.2 \mathrm{mM}$ ethylene glycol-bis( $\beta$-amino-ethyl ether) $\mathbf{N}, \mathbf{N}, \mathbf{N}^{\prime}, \mathbf{N}^{\prime}$-tetra-acetic acid (EGTA), and the protease inhibitors $1 \mu \mathrm{M}$ leupeptin, $1 \mu \mathrm{M}$ pepstatin $\mathrm{A}$ and $0.2 \mathrm{mM}$ phenylmethanesulfonyl fluoride (PMSF); final pH 7.4. Membrane fractions wcre pclleted by centrifugation at $12,000 \times \mathrm{g}$ for $10 \mathrm{~min}$ and washed twice with buffered saline $(130 \mathrm{mM}$ $\mathrm{NaCl}, 10 \mathrm{mM}$ sodium HEPES, $0.01 \% \mathrm{NaN}_{3}, \mathrm{pH} 7.4$ ). Membrane preparations from CTX-treated cells and the corresponding controls were incubated with CTX A-subunit $(10 \mu \mathrm{g} / \mathrm{ml}), 1 \mathrm{mM}$ GTP, 10 to $20 \mu \mathrm{Ci}$ [ $\left.{ }^{32} \mathrm{P}\right] \mathrm{NAD}, 20 \mathrm{mM}$ dithiothreitol (DTT), $20 \mathrm{mM}$ thymidine and $0.1 \%$ Triton X-100 in a total volume of $50 \mu 1$ at $30^{\circ} \mathrm{C}$ for $30 \mathrm{~min}$. Membrane preparations from PTX-treated cells and their controls were incubated with activated PTX $(10 \mu \mathrm{g} / \mathrm{ml}), 1 \mathrm{mM}$ ATP, 5 to 10 
$\mu \mathrm{Ci}\left[{ }^{32}\right.$ P]NAD, $20 \mathrm{mM}$ DTT, $20 \mathrm{mM}$ thymidine and $0.1 \%$ Triton X-100 in a total volume of $50 \mu 1$ at $37^{\circ} \mathrm{C}$ for $30 \mathrm{~min}$. PTX was activated by incubation with 2 $\mathrm{mM}$ ATP and $40 \mathrm{mM}$ DTT for $30 \mathrm{~min}$ at $37^{\circ} \mathrm{C}$ (Gill and Woolkalis, 1988). Reactions were terminated by the addition of $500 \mu \mathrm{l}$ ice-cold buffered saline, and the proteins were pelleted by centrifugation at $12,000 \times \mathrm{g}$ for $20 \mathrm{~min}$. The pelleted proteins were solubilized with sodium dodecyl sulfate (SDS) by boiling for $10 \mathrm{~min}$ and subjected to electrophoresis on $10 \%$ linear gradient SDS-polyacrylamide gels (Laemmli, 1970). Gels were stained for protein with Coomassie Brilliant Blue, dried and autoradiographed using Kodak X-Omat film and an intensifing screen at $-70^{\circ} \mathrm{C}$ for 1 to 4 days. The radioactivity of the bands corresponding to $\alpha$ subunits of $\mathrm{G}$-proteins was measured by scintillation counting.

\section{Statistics}

The amount of radioactive InsPs released is expressed as $\mathrm{dpm} / \mu \mathrm{g}$ protein. Results are reported as means $\pm \mathrm{SD}$. Statistical significance was tested using ANOVA and Fisher's Least Significant Difference.

\section{Results}

\section{Effects of $\mathrm{NaF} / \mathrm{AlCl}_{3}$ and $\mathrm{GTP}-\gamma-\mathrm{S}$ on InsPs release}

In order to probe the involvement of G-proteins, the effects of $\mathrm{NaF}$ plus $\mathrm{AlCl}_{3}$ and the non-hydrolysable GTP analog GTP- $\gamma$-S on InsPs release were examined in intact and permeabilized tissues, respectively (Fig. 1). Basal release of total InsPs was $4990 \pm 1093 \mathrm{dpm}$ / $\mu \mathrm{g}$ protein in the intact CSE and $4925 \pm 1189 \mathrm{dpm} / \mu \mathrm{g}$ protein in the intact VSE. Ten $\mathrm{mM} \mathrm{NaF}$ plus $10 \mu \mathrm{M}$ $\mathrm{AlCl}_{3}$ significantly increased InsPs release 1.8-fold in both tissues. In tissues permeabilized with saponin, basal release of InsPs was essentially unchanged with $4949 \pm 909 \mathrm{dpm} / \mu \mathrm{g}$ protein in CSE and $5406 \pm 780$ $\mathrm{dpm} / \mu \mathrm{g}$ protein in VSE. The release of InsPs was significantly increased 1.8 and 2.1 -fold by $100 \mu \mathrm{M}$ GTP- $\gamma$-S.

Individual InsPs (InsP, $\operatorname{InsP}_{2}$ and $\operatorname{InsP}_{3}$ ) were increased 2.2-, 1.6- and 1.5-fold by $\mathrm{NaF} / \mathrm{AlCl}_{3}$ in CSE and $2.2-, 1.1-$ and 1.2-fold in VSE. GTP- $\gamma$-S $(200 \mu \mathrm{M})$ increased InsP, $\mathrm{InsP}_{2}$ and $\mathrm{InsP}_{3}$ release 3.1-, 2.1- and 1.1-fold in permeabilized CSE, and 2.6-, 1.8- and 1.3in permeabilized VSE, respectively.

\section{Effects of GDP- $\beta-S$ on agonist-stimulated release of InsPs}

Both muscarinic and purinergic $P_{2 y}$ receptors are coupled to PLC in CSE and VSE. To determine the involvement of G-proteins in agonist-stimulated InsPs release, the effect of GDP- $\beta$-S was examined in permeabilized tissues. One mM carbamylcholine (CCh) and $200 \mu$ M ATP- $\gamma$-S enhanced InsPs release to the same

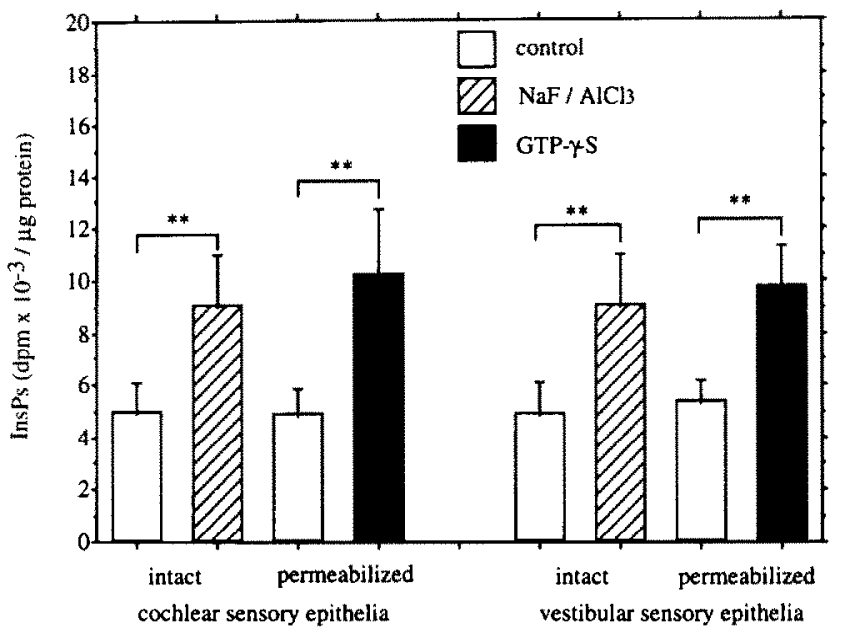

Fig. 1. Effects of NaF plus $\mathrm{AlCl}_{3}$ and of GTP- $\gamma-\mathrm{S}$ on InsPs release. Intact CSE and VSE pre-labeled with $16 \mu \mathrm{Ci}$ myo- $\left[{ }^{3} \mathrm{H}\right]$ inositol as described in 'Methods'. Tissues were then incubated with $10 \mathrm{mM}$ $\mathrm{NaF}$ and $10 \mu \mathrm{M} \mathrm{AlCl}_{3}$ for $30 \mathrm{~min}$ in the presence of $10 \mathrm{mM} \mathrm{LiCl}$. Aiternatively, pre-labeled permeabilized tissues were incubated with $100 \mu \mathrm{M}$ GTP- $\gamma$-S for $30 \mathrm{~min}$ in the presence of $10 \mathrm{mM} \mathrm{LiCl}$. Each bar represents the mean $\pm S D$ of 5 independent experiments. Statistical significance of differences from controls $(* *, P<0.01)$ was determined by ANOVA and Fisher's Least Significant Difference.

extent (Fig. 2) as they did in intact tissues (Ogawa and Schacht, 1993). One hundred $\mu \mathrm{M}$ guanosine $5^{\prime}-\mathrm{O}-(2-$ thiodiphosphate) (GDP- $\beta-S$ ) significantly inhibited carbamylcholine $(\mathrm{CCh})$-stimulated release of InsPs by $22 \%$ and $30 \%$ in CSE and VSE, respectively. Adenosine 5'-O-(3-thiotriphosphate) (ATP- $\gamma$-S)-stimulated release of InsPs was also significantly blocked by $33 \%$ and $21 \%$ in CSE and VSE, respectively.

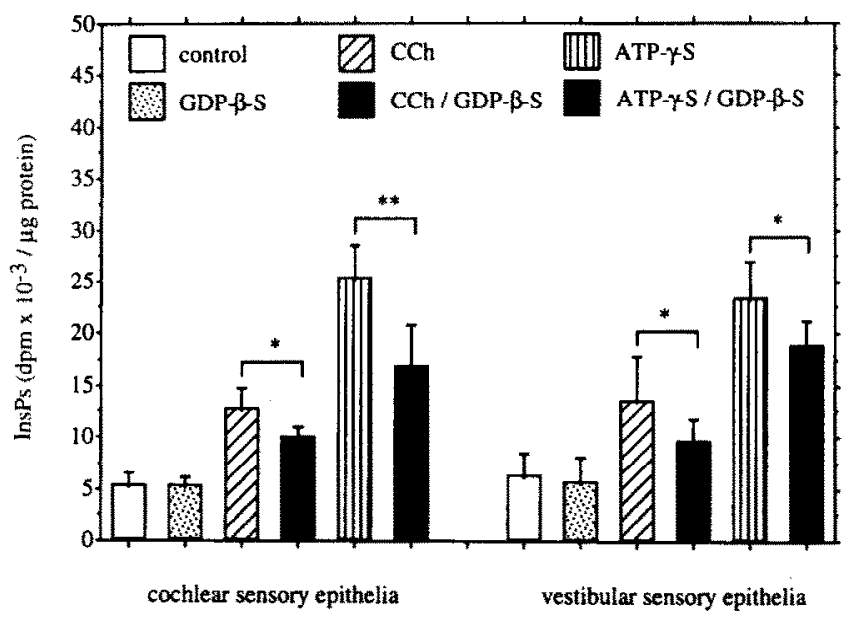

Fig. 2. Effects of GDP- $\beta$-S on agonist-stimulated release of InsPs. Permeabilized CSE and VSE labeled with $16 \mu \mathrm{Ci}$ myo- $\left[{ }^{3} \mathrm{H}\right]$ inositol were incubated with $100 \mu \mathrm{M} \mathrm{GDP}-\beta$-S with or without $1 \mathrm{mM} \mathrm{CCh}$ or $200 \mu \mathrm{M} \mathrm{ATP}-\gamma-\mathrm{S}$ for $30 \mathrm{~min}$ in the presence of $10 \mathrm{mM} \mathrm{LiCl}$ as described in 'Methods'. Each bar represents the mean $\pm \mathrm{SD}$ of 5 independent experiments. Statistical significance of differences from controls ( $\left.^{*}, 0.01<P<0.05,{ }^{* *}, P<0.01\right)$ was determined by ANOVA and Fisher's Least Significant Difference. 
Table 1

CTX does not affect agonist-stimulated release of InsPs

\begin{tabular}{|c|c|c|c|c|}
\hline \multirow{2}{*}{$\begin{array}{l}\text { CTX } \\
(\mu \mathrm{g} / \mathrm{ml})\end{array}$} & \multicolumn{2}{|l|}{ CSE } & \multicolumn{2}{|l|}{ VSE } \\
\hline & $\begin{array}{l}\mathrm{CCh} \\
\text { (\% of } \\
\text { control) }\end{array}$ & $\overline{\mathrm{ATP}} \cdot \gamma-\mathrm{S}$ & $\overline{\mathrm{CCh}}$ & $\overline{\mathrm{ATP}-\gamma-\mathrm{S}}$ \\
\hline none & $192 \pm 65$ & $442 \pm 97$ & $233 \pm 88$ & $375 \pm 104$ \\
\hline 0.01 & $180 \pm 32$ & $310 \pm 124$ & $274 \pm 28$ & $356 \pm 72$ \\
\hline 0.1 & $172 \pm 18$ & $424 \pm 127$ & $261 \pm 129$ & $381 \pm 116$ \\
\hline 1 & $201 \pm 68$ & $346 \pm 116$ & $284 \pm 120$ & $436 \pm 240$ \\
\hline
\end{tabular}

Intact CSE and VSE were preincubated with CTX $(0.01$ to $1 \mu \mathrm{g} / \mathrm{ml})$ for $2 \mathrm{~h}$ followed by incubation with $16 \mu \mathrm{Ci}$ myo- $\left[{ }^{3} \mathrm{H}\right]$ inositol for another $2 \mathrm{~h}$ as described in 'Methods'. Then the tissues were incubated with $1 \mathrm{mM}$ carbamylcholinc or $200 \mu \mathrm{M}$ ATP- $\gamma-\mathrm{S}$ for 30 min in the presence of $10 \mathrm{mM} \mathrm{LiCl}$. Each figure is the mean $\pm \mathrm{SD}$ of 5 independent experiments. Values for CTX-treatment were not different from controls as determined by ANOVA.

Accumulation of individual InsP, InsP $_{2}$ and $\operatorname{InsP}_{3}$ induced by $\mathrm{CCh}$ was decreased by $20 \%, 31 \%$ and $57 \%$ by GDP- $\beta$-S in CSE and $19 \%, 25 \%$ and $53 \%$ in VSE. Additionally, GDP- $\beta$-S blocked the ATP- $\gamma$-S stimulated release of InsP, InsP $\mathrm{P}_{2}$ and $\mathrm{InsP}_{3}$ by $35 \%, 11 \%$ and $36 \%$ in permeabilized CSE, and $23 \%, 5 \%$ and $24 \%$ in permeabilized VSE.

Effects of cholera and pertussis toxins on agonist-stimulated release of InsPs

In order to classify G-proteins coupled to muscarinic and to purinergic $P_{2 y}$ receptors, tissues were incubated with CTX or PTX for $4 \mathrm{~h}$ at $37^{\circ} \mathrm{C}$ followed by agonist stimulation. The presence of toxins did not affect basal release of InsPs. In addition, neither CChnor ATP- $\gamma$-S-stimulated release of InsPs was affected by either toxin (Tables 1 and 2). Agonist-stimulated release of individual InsPs was also not affected by these toxins.
Table 2

PTX does not affect agonist-stimulated release of InsPs

\begin{tabular}{|c|c|c|c|c|}
\hline \multirow{2}{*}{$\begin{array}{l}\text { PTX } \\
(\mu \mathrm{g} / \mathrm{ml})\end{array}$} & \multicolumn{2}{|l|}{ CSE } & \multicolumn{2}{|l|}{ VSE } \\
\hline & $\begin{array}{l}\mathrm{CCh} \\
\text { (\% of } \\
\text { control) }\end{array}$ & $\overline{\mathrm{ATP}}-\gamma-\mathrm{S}$ & $\overline{\mathrm{CCh}}$ & $\overline{\mathrm{ATP}-\gamma-\mathrm{S}}$ \\
\hline none & $253 \pm 62$ & $397 \pm 77$ & $233 \pm 77$ & $396 \pm 165$ \\
\hline 0.01 & $209 \pm 49$ & $467 \pm 176$ & $264 \pm 80$ & $527 \pm 272$ \\
\hline 0.1 & $257 \pm 64$ & $433 \pm 208$ & $238 \pm 55$ & $363 \pm 104$ \\
\hline 1 & $249 \pm 9$ & $446 \pm 140$ & $243 \pm 32$ & $442 \pm 129$ \\
\hline
\end{tabular}

Intact CSE and VSE were preincubated with PTX $(0.01$ to $1 \mu \mathrm{g} / \mathrm{ml})$ for $2 \mathrm{~h}$ followed by incubation with $16 \mu \mathrm{Ci} m y o-\left[{ }^{3} \mathrm{H}\right]$ inositol for another $2 \mathrm{~h}$ as described in 'Methods'. Then the tissues were incubated with $1 \mathrm{mM}$ carbamylcholine or $200 \mu \mathrm{M} \mathrm{ATP}-\gamma$-S for 30 min in the presence of $10 \mathrm{mM} \mathrm{LiCl}$. Each figure is the mean \pm SD of 5 independent experiments. Values for PTX-treatment were not different from controls as determined by ANOVA.

\section{ADP-ribosylation by toxins}

Two proteins with molecular weights of $52 \mathrm{kDa}$ and $45 \mathrm{kDa}$ were $\left[{ }^{32} \mathrm{P}\right] \mathrm{ADP}$-ribosylated by the CTX A-subunit in CSE and VSE (Fig. 3a lane 2 and 5). A $40 \mathrm{kDa}$ protein was $\left[{ }^{32} \mathrm{P}\right] \mathrm{ADP}$-ribosylated by activated PTX in these tissues (Fig. $3 b$ lane 2 and 5). No radioactivity was incorporated into the protein bands when the membrane fraction was incubated with $\left[{ }^{32} \mathrm{P}\right] \mathrm{NAD}$ without toxins (Fig. 3a,b; lane 1 and 4). Under the same conditions as the assay of inositol phosphate hydrolysis, [ $\left.{ }^{32} \mathrm{P}\right] \mathrm{ADP}$-ribosylation of the $52 \mathrm{kDa}$ and $45 \mathrm{kDa}$ proteins was decreased by $59 \pm 12 \%$ in CSE and by $55 \pm$ $19 \%$ in VSE $(\mathrm{n}=5)$ by pretreatment with $1 \mu \mathrm{g} / \mathrm{ml}$ CTX (Fig. 3a, lane 3 and 6). [ $\left.{ }^{32} \mathrm{P}\right] A$ ADP-ribosylation of the $40 \mathrm{kDa}$ substrate was reduced by $70 \pm 15 \%$ in CSE and by $73 \pm 14 \%$ in $/ S E(n=5)$ by pretreatment with $1 \mu \mathrm{g} / \mathrm{ml}$ PTX (Fig. 3b, lane 3 and 6). (a) CTX
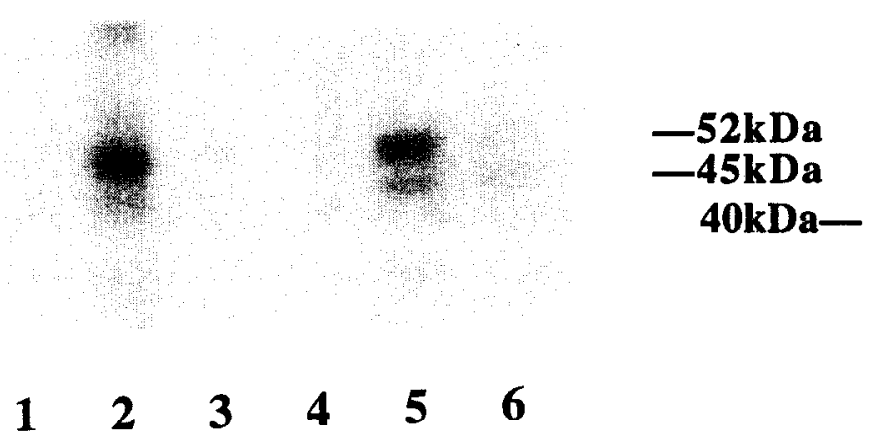

Fig. 3. SDS-PAGE separation of membrane proteins [ ${ }^{32}$ P]ADP-ribosylated by CTX (Fig. 3a) or PTX (Fig. 3b). CSE (lanes 1, 2 and 3) and VSE (lanes 4,5 and 6 ) were pre-incubated with or without CTX or PTX for $4 \mathrm{~h}$ at $37^{\circ} \mathrm{C}$. Then, the membrane fractions were $\left[{ }^{32} \mathrm{P}\right] \mathrm{ADP}-\mathrm{ribosylated}$ in the presence of the respective toxin as described in 'Methods'. Lanes 1 and 4 represent controls incubated without CTX A-subunit or activated PTX; lanes 2 and 5 are from pre-incubations without toxin; lanes 3 and 6 from pre-incubations with toxin. 


\section{Discussion}

The present study clearly demonstrates the involvement of G-proteins in the phosphoinositide second messenger system both in the cochlear and vestibular sernsory epithelia. The type of G-protein, however, is unlike any of those characterized in the inner ear so far.

In support of the involvement of G-proteins in the regulation of PLC activity, GTP- $\gamma$-S stimulates InsPs release. GTP itself is not an effective activator of G-proteins, because it is easily hydrolyzed to GDP. The non-hydrolyzable analog GTP- $\gamma$-S, however, has been shown to enhance InsPs release in various organs (Litosch et al., 1985; Cockcroft and Gompert, 1985). The implication that PLC activation is regulated by G-proteins in the CSE and VSE is corroborated by the fact that $\mathrm{NaF}$ and $\mathrm{AlCl}_{3}$ also enhanced InsPs release. The combination of these compounds, presumably acting as fluoroaluminate $\left(\mathrm{AlF}_{4}^{-}\right)$, mimics the $\gamma$-phosphate group of GTP and activates G-proteins in intact cells (Sternweis and Gilman, 1982; Katada et al., 1984; Cockcroft and Taylor, 1987, Marc et al., 1988; Fischer et al., 1993). Furthermore, individual InsPs including $\mathrm{InsP}_{3}$, were also increased by GTP- $\gamma$-S or $\mathrm{AlF}_{4}^{-}$, suggesting that the hydrolysis of PtdIns $\mathrm{P}_{2}$ was a main pathway to release InsPs.

In a second line of evidence, the agonist-mediated release of InsPs was significantly blocked by GDP- $\beta$-S. This GDP analog inhibits the activation of G-protein, and its effect was evident on the activation of both muscarinic and purinergic $\mathrm{P}_{2 \mathrm{y}}$ receptors in the CSE and VSE. The sum of these results provides convincing evidence that G-proteins are coupled to the phosphoinositide second messenger system in CSE and VSE. This general evidence, however, does not indicate which type of G-protein is involved.

Both CTX- and PTX-sensitive G-proteins are found in the cochlea. The toxins are specific probes for G-proteins as they catalyze the irreversible covalent addition of an ADP-ribosyl group from intracellular $\mathrm{NAD}^{+}$to the $\alpha$ subunit of $\mathrm{G}_{\mathrm{s}}$ (CTX) or $\mathrm{G}_{\mathrm{i}}$ (PTX). Thus, the ADP-ribosylation of proteins with molecular weights of $52 \mathrm{kDa}$ and $45 \mathrm{kDa}$ catalyzed by CTX is consistent with the presence of $\mathrm{G}_{\mathrm{s} \alpha-1}$ or $\mathrm{G}_{\mathrm{s} \alpha-2}$ and $\mathrm{G}_{\mathrm{s} \alpha-3}$ or $\mathrm{G}_{\mathrm{s} \alpha-4}$, respectively. Proteins with a molecular weight of $40 \mathrm{kDa}$ which are ADP-ribosylated by PTX are considered to be $G_{i-1 a}, G_{i-2 a}$ or $G_{i-3 a}$ (Kaziro et al., 1991). These findings are in agreement with the demonstration of $\alpha$-subunits of inhibitory G-proteins $\left(G_{i 1}, G_{i 2}\right.$ and $\left.G_{i 3}\right)$, other G-protein $\left(G_{o}\right)$ and stimulatory G-protein $\left(\mathrm{G}_{\mathrm{s}}\right)$ in the organ of Corti of guinea pig (Canlon et al., 1991; Tachibana et al., 1992). None of these toxin-sensitive G-proteins, however, seems involved in the coupling of cochlear and vestibular muscarinic and purinergic receptors to phospholipase C.
This finding in CSE and VSE is in agreement with the characterization of PLC-coupled G-proteins in most tissues. G-proteins associated with muscarinic receptors have generally been reported to be CTX- and PTX-insensitive (Masters et al., 1985; Dunlop and Larkins, 1986; Helper and Harden, 1986; Sasaguri et al., 1986; Schnefel et al., 1988; Fleming et al., 1989) or at best incompletely blocked at high PTX concentrations $(10 \mu \mathrm{g} / \mathrm{ml}$; Mei et al., 1988). In contrast, patchclamping studies of isolated cochlear hair cells inferred that acetylcholine-stimulation of the inositol phosphate cascade was mediated through a PTX-sensitive G-protein (Kakehata et al., 1992; Kakehata et al., 1993). However, the acetylcholine action was measured as an activation of a calcium-activated $\mathrm{K}^{+}$-channel, not InsPs release directly. In addition, this type of response is blocked by both atropine and d-tubocurare (Housley and Ashmore, 1991) in contrast to the selective inhibition of InsPs release by atropine only (Niedzielski et al., 1992; Ogawa and Schacht, 1993). Thus, G-proteins related to a calcium-activated $\mathrm{K}^{+}$-channel in outer hair cells may be different from G-proteins coupled to the phosphoinositide second messenger system in the CSE and VSE.

The types of G-proteins involved in purinergic signal transduction remain to be established. Partial inhibition of InsPs release by PTX at purinergic receptors has been reported in some tissues (Haggblad and Heilbronn, 1988; Okajima et al., 1989; Dubyak et al., 1990; Nanoff et al., 1990; Yamada et al., 1992). In these cases, InsPs release by low concentration of purinergic agonists was blocked by PTX, while the toxin produced no or only partial inhibition at high agonist concentrations. This is consistent with our study in which InsPs release induced by a high concentration of ATP- $\gamma$-S was unaffected by toxins.

Finally, the ineffectiveness of the toxin action can only be used as an argument if it is assured that the toxin actually entered the intact tissues of the CSE and VSE. ADP-ribosylation demonstrating the presence of G-proteins was conducted in tissue homogenates, and thus did not indicate whether the toxin can enter the cells under the experimental conditions of InsPs release. Two points can be made. First, the conditions used here for both CTX and PTX have been shown to be effective on other cell types. For example, $10 \mathrm{nM}$ CTX incubated with mouse neuroblastoma cells was internalized with a half-life of 2 h (Fishman, 1982). In rat $\mathrm{C} 6$ glioma cells, the half-maximal effective concentration for a $2 \mathrm{~h}$ incubation was $100 \mathrm{ng} \mathrm{PTX} / \mathrm{ml}$ (Katada et al., 1982). Second, the prior incubation of intact tissues with toxins in our experiments led to a significant decrease of ADP-ribosylation, indicating that the toxin was able to enter the cells.

In summary, G-proteins are key components in the regulation of intracellular signal transduction. We have 
previously postulated that the efferent system regulates or modulates hair cell functions through the phosphoinositide second messenger cascade. We can now conclude that muscarinic and purinergic receptors in CSE and VSE are coupled to phospholipase $C$ through $G_{p}$-like G-proteins. In order to elucidate the precise role of $\mathrm{Gp}$ in signal transduction in the inner ear we need further characterization of these proteins by molecular biological approaches and studies of their involvement in hair cell physiology and pathophysiology.

\section{Acknowledgements}

This work was supported by research grant DC00078 from the National Institute of Health.

\section{References}

Berridge, M.J., Dawson, R.M.C., Downes, C.P., Heslop, J.P. and Irvine, R.F. (1983) Changes in the levels of inositol phosphates after agonist-dependent hydrolysis of membrane phosphoinositides. Biochem. J. 212, 473 482 .

Bradford, M.M. (1976) A rapid and sensitive method for the quantitation of microgram quantities of protein utilizing the principle of protein-dye binding. Anal. Biochem. 72, 248-254.

Canion, B., Homburger, V. and Bockaert, J. (1991) The identification and localization of the guanine nucleotide protein Go in the auditory system. Eur. J. Neurosci. 3, 1338-1342.

Cockcroft, S. and Gomperts, B.D. (1985) Role of guanine nucleotide binding protein in the activation of polyphosphoinositide phosphodiesterase. Nature $314,534-536$.

Cockcroft, S. and Taylor, J.A. (1987) Fluoroaluminates mimic GTPgS in activating the polyphosphoinositide phosphodiesterase of hepatocyte membranes: role for the guanine nucleotide binding protein, Gp in signal transduction. Biochem. J. 241, 409-414.

Dean, N.M. and Beaven, M.A. (1989) Methods for the analysis of inositol phosphate. Anal. Biochem. 183, 199-209.

Dubyak, G.R. and Cowen, D.S. (1990) Activation of inositol phosphlipid specific phospholipase $C$ by $P 2$-purinergic receptors in human phagocytic leukocytes. Role of pertussis toxin-sensitive $G$ proteins. Ann. N.Y. Acad. Sci. 603, 227-245.

Dunlop, M.E. and Larkins, R.G. (1986) Muscarinic agonist and guanine nucleotide activation of polyphosphoinositide phosphodiesterase in isolated islet-cell membrane. Biochem. J. 240, 731-737.

Fischer, S.K., McEwen. E.. Kunkle, C., Thompson, A.K, and Slowiejko, D. (1993) Contribution of $G$ protein activation to fluoride stimulation of phosphoinositide hydrolysis in human neuroblastoma cells. J. Neurochem. 60, 1800-1805.

Fishman, P.H. (1982) Internalization and degradation of cholera toxin by cultured cells: relationship to toxin action. J. Cell Biol. $93,860-865$.

Fleming, N., Sliwinski-Lis, E. and Burke, D.N. (1989) G regulatory proteins and muscarinic receptor signal transduction in mucous acini of rat submandibular gland. Life Sci. 44, 1027-1035.

Gill, D.M. and Meren, R. (1978) ADP-ribosylation of membrane proteins catalyzed by cholera toxin: basis of the activation of adenylate cyclase. Proc. Natl. Acad. Sci. USA. 75, 3050-3054.

Gill, D.M. and Woolkalis, M. (1988) [ ${ }^{32}$ P]ADP-ribosylation of proteins catalyzed by cholera toxin and related heat-labile enterotoxins. Methods Enzymol. 165, 235-245.
Gilmann, A.G. (1987) G proteins: transducers of receptor-generated signals. Ann. Rev. Biochem. 56, 615-649.

Guiramand, J., Mayat, E., Bartolami, S., Lenoir, M., Rumigny, J.-F., Pujol, R. and Recasens, M. (1990) A M3 muscarinic receptor coupled to inositol phosphate formation in the rat cochlea? Biochem. Pharmacol. 39, 1913-1919.

Haggblad, J. and Heilbronn, E. (1988) P2-purinoceptor-stimulated phosphoinositide turnover in chick myotubes. Calcium mobilization and the role of guanyl nucleotide-binding protein. FEBS Lett. 235, 133-136.

Helper, J.R. and Harden, T.K. (1986) Guanine nucleotide-dependent pertussis-toxin-insensitive stimulation of inositol phosphate formation by carbachol in a membrane preparation from human astrocytoma cells. Biochem. J. 239, 141-146.

Hepler, J.R. and Gilman, A.G. (1992) G proteins. Trends Biochem. Sci. 17, 383-387.

Housley, G.D. and Ashmore, J.F. (1991) Direct measurement of the action of acetylcholine on isolated outer hair cells of the guinea pig cochlea. Proc. Royal Soc. B 244, 161-167.

Kakehata, S., Nakagawa. T., Akaike, N. and Takasaka, T. (1992) ACh activates inositol phosphate cascade via a PTX-sensitive G-protein in dissociated outer hair cells of guinea-pig cochlea. Proc. Sendai Symp. 2, 25-29.

Kakehata, S., Nakagawa, T., Takasaka, T. and Akaike, N. (1993) Cellular mechanism of acetylcholine-induced response in dissociated outer hair cells of guinea-pig cochlea. J. Physiol. 463, 227244.

Katada, T, Amano, T. and Ui, M. (1982) Modulation by islet-activating protein of adenylate cyclase activity in C6 glioma cells. J. Biol. Chem. 257, 3739-3746.

Katada, T., Northup, J.K., Bokoch, G.M., Ui, M. and Gilman, A.G. (1984) The inhibitory guanine nucleotide-binding regulatory component of adenylate cyclase. Subunit dissociation and guanine nucleotide dependent hormonal inhibition. J. Biol. Chem. 259, 3578-3585

Kaziro, Y., Itoh, H., Kozasa, T., Nakafuku, M. and Satoh, T. (1991) Structure and function of signal-transducing GTP-binding proteins. Annu. Rev. Biochem. 60, 344-400.

Laemmli, U.K. (1970) Cleavage of structural proteins during the assembly of the head of bacteriophage T4, Nature 227, 680-685.

Litosch, I., Wallis, C. and Fain, J.N. (1985) 5-hydroxytryptaminc stimulates inositol phosphte production in a cell-free system blowfly salivary glands. J. Biol. Chem. 260, 5464-5471.

Marc S., Leiber, D. and Harbon, S. (1988) Fluoroaluminates mimic muscarinic- and oxytocin-receptor-mediated generation of inostol phosphates and contraction in the intact guinea-pig myometrium. Biochem. J. 255, 705-713.

Masters, S.B., Martin, M.W., Harden, T.K. and Brown, J.H. (1985) Pertussis toxin does not inhibit muscarinic-receptor-mediated phosphoinositide hydrolysis or calcium mobilization. Biochem. J. 227, 933-937.

Mei, L., Yamamura, H.I. and Roeske, W.R. (1988) Muscarinic receptor-mediated hydrolysis of phosphatidylinositols in human neuroblastoma (SH-SY5Y) cells is sensitive to pertussis toxin. Brain Res. 447, 360-363.

Nanoff, C., Freissmuth, M., Tuisl, E. and Schutz, W. (1990) P2-, but not P1-purinoceptors mediate formation of 1,4,5-inositol trisphosphate and its metabolites via a pertussis toxin-insensitive pathway in the rat renal cortex. Br. J. Pharmacol. 100, 63-68.

Niedzielski, A.S. and Schacht, J. (1991) Phospholipid metabolism in the cochlea: Differences between base and apex. Hear. Res. 57, $107-112$.

Niedzielski, A.S., Ono, T. and Schacht, J. (1992) Cholinergic regulation of the phosphoinositide second messenger system in the guinea pig organ of Corti. Hear. Res. 59, 250-254.

Niedzielski, A.S. and Schacht, J. (1992) P2 purinoceptors stimulate 
inositol phosphate release in the organ of Corti. NeuroReport 3 , 273-275.

Ogawa, K. and Schacht, J. (1993) Receptor-mediated release of inositol phosphates in the cochlear and vestibular sensory epithelia of the rat. Hear. Res. 69, 207-214.

Okajima, F., Sata, K., Nazarea, M., Sho, K. and Kondo, Y. (1989) A permissive role of pertussis toxin substrate G-protein in P2purinergic stimulation of phosphoinositide turnover and arachidonate release in FRTL-5 thyroid cells. Cooperative mechanism of signal transduction systems. J. Biol. Chem. 264, 13029-13037.

Sasaguri, T., Hirata, M., Itoh, T., Koga, T. and Kuriyama, H. (1986) Guanine nucleotide binding protein involved in muscarinic responses in the pig coronary artery is insensitive to islet-activating protein. Biochem. J. 239, 567-574.

Schnefel, S., Banfic, H., Eckhardt, L., Schultz, G. and Schulz, I.
(1988) Acetylcholine and cholecystokinin receptors functionally couple by different $\mathrm{G}$ proteins to phospholipase $\mathrm{C}$ in pancreatic acinar cells. FEBS Lett. 230, 125-130.

Sternweis, P.C. and Gilman, A.G. (1982) Proc. Natl. Acad. Sci. USA. $79,4888-4891$.

Sternweis, P.C. and Smrcka, A.V. (1992) Regulation of phospholipase $\mathrm{C}$ by $\mathrm{G}$ proteins. Trends Biochem Sci 17, 502-506.

Tachibana, M., Wilcox, E., Yokotani, N., Schneider, M. and Fex, J. (1992) Selective amplification and partial sequencing of cDNAs encoding $\mathrm{G}$ protein $\alpha$ subunits from cochlear tissues. Hear. Res. $62,82-88$.

Yamada, M., Hamamori, Y., Akita, H. and Yokoyama, M. (1992) P2-purinoceptor activation stimulates phosphoinositide hydrolysis and inhibits accumulation of cAMP in cultured ventricular myocytes. Circ. Res. 70, 477-485. 